\title{
Aristolochia brunneomaculata, a new threatened species of Aristolochiaceae from the Atlantic Forest in Bahia, Brazil
}

\author{
Ivan Silva Abreu ${ }^{1 *} \&$ Ana Maria Giulietti ${ }^{1,2, a}$ \\ ${ }^{1}$ Programa de Pós-graduação em Botânica, Universidade Estadual de Feira de Santana, Feira de Santana, Bahia, Brasil. \\ ${ }^{2}$ Instituto Tecnológico VALE de Desenvolvimento Sustentável, Belém, Pará, Brasil.
}

\begin{abstract}
We describe and illustrate Aristolochia brunneomaculata, a new species from the Atlantic Forest in Bahia state, Brazil, a region known for its high number of endemic and threatened species, such as the one described here. The new species is known only from a small population in a disturbed area, near a major industrial complex.

Additional key words: conservation, taxonomy.
\end{abstract}

Resumo (Aristolochia brunneomaculata, uma espécie nova e ameaçada de Aristolochiaceae da Mata Atlântica na Bahia, Brasil) - Neste trabalho, descrevemos e ilustramos Aristolochia brunneomaculata, uma nova espécie da Mata Atlântica do estado da Bahia, Brasil, uma região conhecida pelo grande número de espécies endêmicas e ameaçadas, como a descrita aqui. A nova espécie é conhecida somente por uma pequena população, em uma área antropizada, próxima a um grande polo industrial.

Palavras-chave adicionais: conservação, taxonomia.

The monophyletic genus Aristolochia L., with approximately 550 species, is the most diverse in the family Aristolochiaceae and has a pantropical distribution (Neinhuis 2005; Ohi-Toma et al. 2006; Wanke et al. 2006; González 2012). Ninety-two accepted species of Aristolochia are recorded for Brazil, approximately $40 \%$ of which are endemic (Barros et al. 2015). They occur in all phytogeographic dominions and various species are characteristic of forested areas. Although there are a few herbaceous species in Brazil, the majority have a twining habit and overall there is great morphological diversity among them (Hoehne 1927, 1942).

Only $7.25 \%$ of the original area of Brazil's Atlantic Forest remains, and in the state of Bahia, less than $4 \%$, consisting only of discontinuous fragments (Thomas et al. 1998; Câmara 2003). These figures clearly show the fragility of what remains of this phytogeographic dominion and the great need to intensify research and conservation efforts focussed on it. In regard to Aristolochia, it is highly significant that in the last 15 years, when systematic studies in this dominion have intensified, five new species have been discovered in the Atlantic Forest of the states of Bahia and Espírito Santo (González 1998, 2000, 2011; Freitas et al. 2013, 2014).

Twenty species of Aristolochia have been recorded during a survey of the family Aristolochiaceae for the Flora of Bahia (Abreu \& Giulietti 2016 in press). The aim of the present paper is to formally describe and name one of these newly discovered species from the Atlantic Forest of Bahia.

\footnotetext{
*Corresponding author: ivanabreuacad@gmail.com; aana.giulietti@vale.org

Corresponding editor: Alessandro Rapini

Submitted: 2 maio 2016; accepted: 18 jul. 2016
}

First published: 12 ago. 2016; final version: 25 out. 2016
Aristolochia brunneomaculata I.Abreu \& Giul., sp. nov. TYPE:-BRASIL. BAHIA: Camaçari, margem da rodovia BA-535, dentro do polo industrial e próximo ao prédio da Companhia de Bebidas das Américas (Ambev), 1240'36.5"S, 38¹9'46"W, 65 m a.s.l., 19 Mar. 2015 (fl., fr.), I.S. Abreu 135 (holotype HUEFS, isotype ALCB).

Figures 1-3.

Aristolochia brunneomaculata resembles Aristolochia tamnifolia (Klotzsch) Duch. in its vegetative and inflorescence morphology, but differs in the greenish-yellow colour of the external surface of the perianth (vs. vinaceous), by the size of the lower part of the perianth tube (utricle) ca. $2.3 \times 1.7 \mathrm{~cm}$ (vs. c. $1.7 \times 1.3 \mathrm{~cm}$ ), the lower lip c. $1.5 \mathrm{~cm}$ long (vs. c. 0.5 $\mathrm{cm})$ and by the upper lip of the perianth not revolute (vs. revolute), with its internal surface not fimbriate (vs. fimbriate).

Twining vine. Stems glabrous, not corky when mature. Young branches cylindrical, internodes 3.6$13.4 \mathrm{~cm}$ long. Leaves with petiole $0.7-2.6 \mathrm{~cm}$ long, glabrous, cylindrical throughout; lamina broadly ovate, 5.3-10 × 6-11 cm, chartaceous, glabrous on both sides, base cordate to lobate, not peltate, sinus $1-2.3 \mathrm{~cm}$ deep, apex acute to mucronate, basal primary veins 5 . Axillary prophylls (pseudostipules) absent. Flowers 1 or 2, arranged in axillary or cauliflorous short rhipidia, rachis c. $0.6 \mathrm{~cm}$ long, internodes c. $0.2 \mathrm{~cm}$ long, subtending sessile deltoid bracts c. $0.2 \times 0.2 \mathrm{~cm}$. Pedicel c. $0.8 \mathrm{~cm}$ long, glabrous. Outer surface of perianth glabrous, yellowish green; lower tube (utricle) ovoid, c. $2.3 \times 1.7 \mathrm{~cm}$, inner surface covered with white trichomes, except for macula with vinaceous trichomes, behind syrinx a brown circle bordering a region of translucent cells at base of lower tube (utricle); syrinx unequal, c. $0.5 \mathrm{~mm}$ wide; upper tube c. $2.4 \times 0.4 \mathrm{~cm}$, inner surface covered by white 


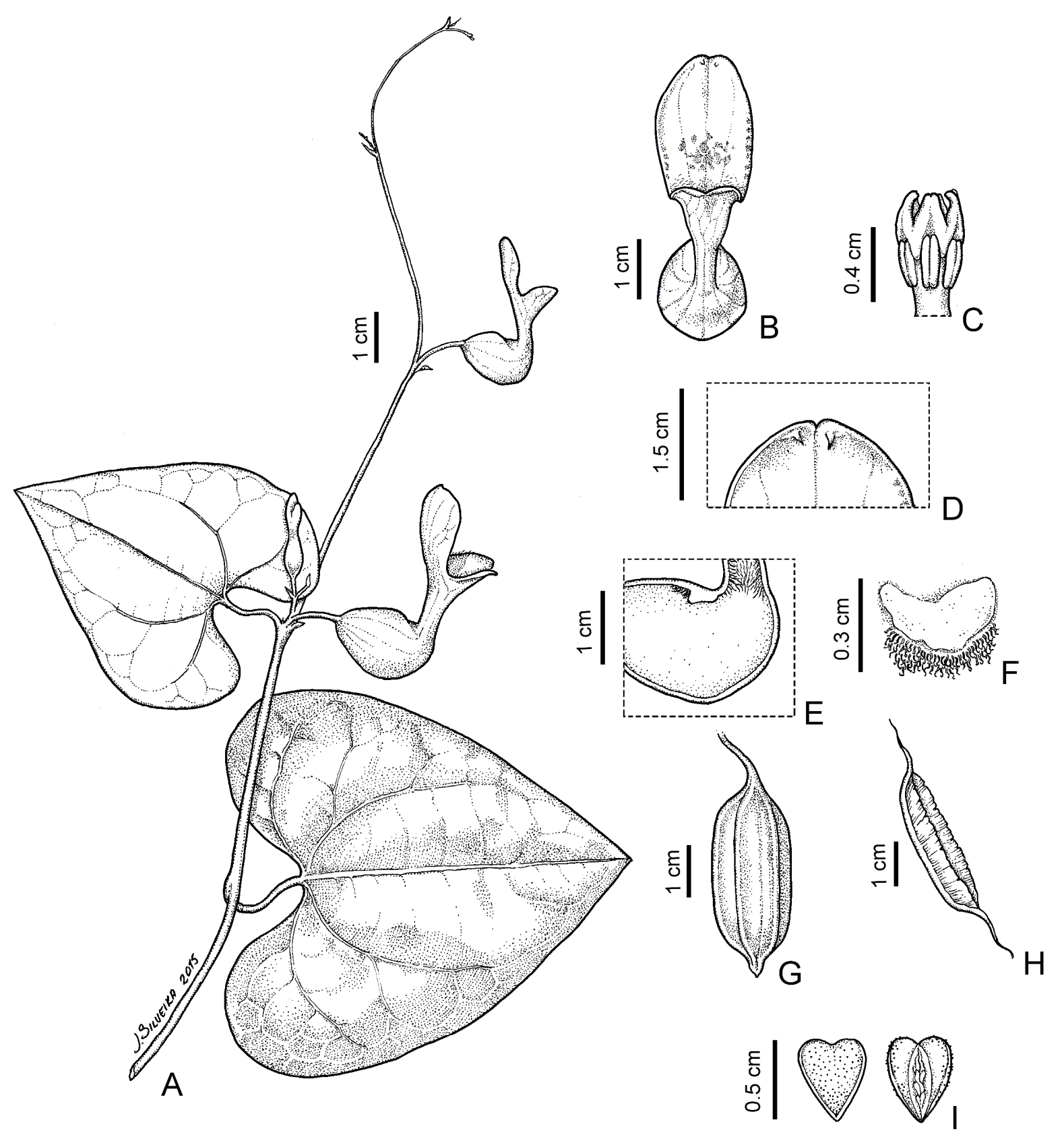

Figure 1. Aristolochia brunneomaculata: A- shoot with leaves and inflorescences; B- perianth, frontal view; C- gynostemium; D- upper lip, with emarginate apex bearing two glands with multiseriate trichomes; E- lower tube ("utricle"), longitudinal section showing the syrinx in lateral view; F- syrinx, seen from within the lower tube; G- capsule; H- capsule locule with fibrous septa; I- seed, showing upper and lower surfaces (drawnings by I. Abreu and J. Silveira).

trichomes, with rose-coloured apex, proximal diameter c. $0.4 \mathrm{~cm}$, distal c. $1 \mathrm{~cm}$; lower lip elliptical, c. $1.5 \times$ $1.5 \mathrm{~cm}$, inner surface covered by white trichomes with rose-coloured apex, margin revolute, apex emarginate; upper lip elliptical, c. $2.2 \times 1.3 \mathrm{~cm}$, margin flat, apex mucronate, inner surface glabrous with two fimbriate glands near apex, brown maculae concentrated in lower half and margin. Ovary c. $0.8 \mathrm{~cm}$ long, glabrous. Gynostemium 6-lobed, c. $0.4 \mathrm{~cm}$ long, stipe c. $1.5 \mathrm{~mm}$ long, anthers linear, c. $3 \mathrm{~mm}$ long. Capsules ellipsoid, 2.9-3.3 × 1.3-1.5 cm, 5- or 6-locular, hexagonal or pentagonal in cross section, dehiscence acropetally, apical rostrum cylindrical, c. $0.4 \mathrm{~cm}$ long, septae fibrous. Seeds broadly ovate, $3-4 \times 3.5-4.5 \mathrm{~mm}$, concave-convex, not winged, testa warty, raphe protruding.

Additional specimen examined (paratype) - BRASIL. BAHIA: Camaçari, Área Controle da Caraíba Metais, 1240'17"S, 38²9'40"W, 49 m a.s.1., 1 Dec. 1982 (fl., fr.), L.R. Noblick et al. 2261 (CEPEC, HUEFS).

Distribution and habitat. The only known population of Aristolochia brunneomaculata occurs 

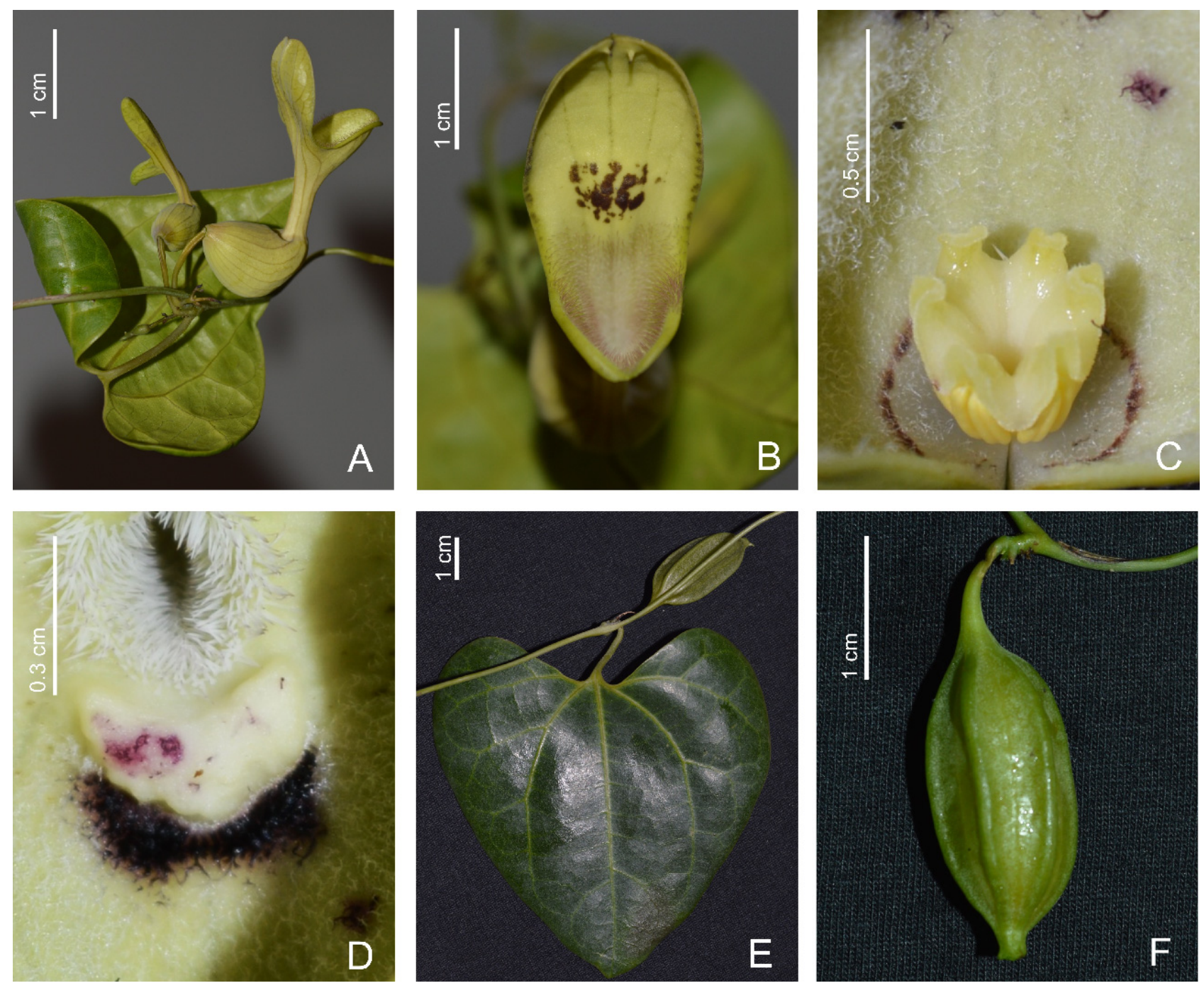

Figure 2. Aristolochia brunneomaculata: A- leafy shoot with two inflorescences; B- perianth, frontal view; C- gynostemium; D- interior of the lower tube ("utricle"), showing the syrinx and the opening into the upper tube; E- leafy shoot with an immature capsule; F- immature capsule (photos by Ivan Abreu).

near the east coast of Bahia state, in the municipality of Camaçari (Figure 3). This municipality lies within the Atlantic Forest dominion, which here consists of disturbed fragments of the vegetation type "mata de tabuleiro", at elevations between 50 and $65 \mathrm{~m}$ a.s.l., with rare individuals of the species near the roads running through the area.

Phenology. The population was observed to produce flowers and fruits in December and March. The Atlantic Forest of the region of Camaçari has a mean annual rainfall of c. $1.608 \mathrm{~mm}$ throughout the year (CPRM 2009), with lower mean rainfall between December and April and the highest between May and July.

Conservation status. The area where the single population of Aristolochia brunneomaculata occurs is the petrochemical complex of Camaçari (Polo Petroquímico de Camaçari), and is exposed to environmental pressures caused by industrial activity and reforestation projects using exotic species of Pinus and Eucalyptus. Aristolochia brunneomaculata was observed only in forest fragments that include native species of the Atlantic Forest and does not occur in the extensive reforested areas. A thorough search was made within the overall area where the species could have been expected to occur, but without success. The known population occupies a total area of approximately 12 $\mathrm{km}^{2}$ and consists of about 10 individuals. Using the IUCN (2001), together with the associated habitat conditions and environmental pressures, we tentatively conclude that this should be considered a species in danger of extinction (EN), according to the criteria A3bce, B2b(i, ii, iii), C1 and D2.

Etymology. The specific epithet refers to the spots on the inner surface of the upper perianth lip, which are characteristic of the species (from Latin brunneus $=$ brown and maculatus $=$ spotted).

Notes. The vegetative and inflorescence morphology of Aristolochia brunneomaculata are superficially similar to those of $A$. tamnifolia, another Bahian species, which explains why the only previous collection, made in 1982, was identified as $A$. tamnifolia. Both species are found in the vegetation 

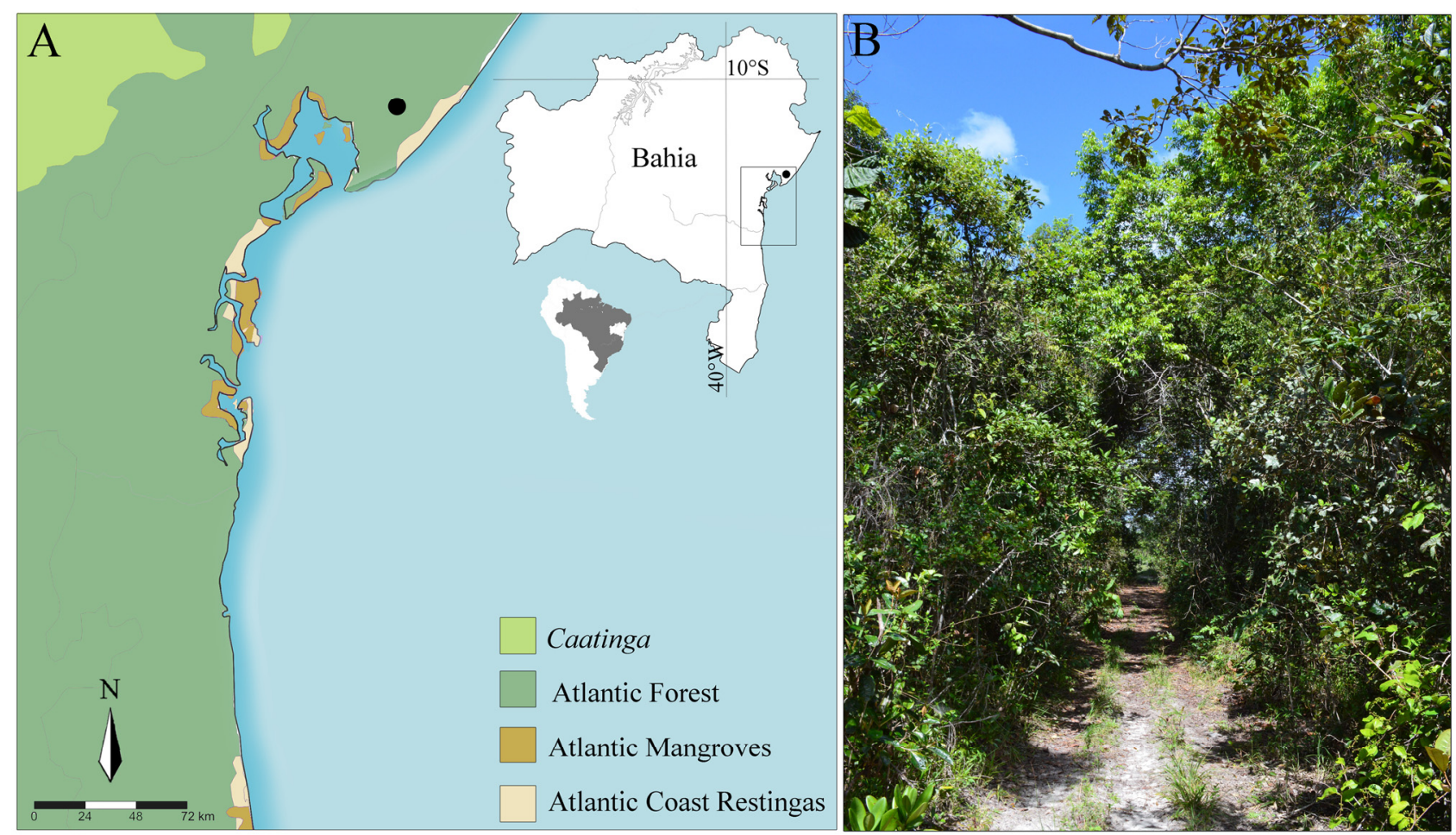

Figure 3. Geographical distribution of Aristolochia brunneomaculata. A- location on the Atlantic Forest of Bahia. B- vegetation type where the species occurs.

type "mata de tabuleiro", near the coast, but $A$. tamnifolia occurs in other areas in the Northeast and Southeast regions of Brazil. In Bahia, the nearest populations of the two species are approximately 56 $\mathrm{km}$ distant. The difference in perianth colour between A. brunneomaculata and A. tamnifolia is the most striking field character by which to distinguish these two twining species, followed by the presence in $A$. tamnifolia of large, dark and very obvious fimbriae on the inner surface of the upper perianth lobe, which are absent or vestigial in A. brunneomaculata. Both species also have ramiflorous rhipidia and similar leaf shape. The widely ovate leaf blades also resemble those of Aristolochia assisii J.Freitas, Lírio \& F.González, but this latter species is easily distinguished by its erect, herbaceous habit, among other differences (Table 1).

The rhipidia of Aristolochia brunneomaculata are reduced to a pair of flowers or one solitary flower and are similar to those of other species, such as $A$. birostris Duch. and A. disticha Mast. This type of inflorescence was reported to Aristolochia by Nair (1961). We assign our new species to Aristolochia sect. Gymnolobus subsect. Hexandrae Duch., which is characterized by a hexamerous gynostemium. The capsules are generally formed of five carpels and present five locules. In the holotype plant, however, we observed one capsule with six locules. The flowers of this species did not have a scent detectable to human observers, but 32 diptera and one coleopteran were collected within the perianth.

\section{ACKNOWLEDGEMENTS}

This study is part of the Masters dissertation of the first author, carried out in the Postgraduate Programme in Botany at the State University of Feira de Santana (PPGBot-UEFS). We thank the curators of the herbaria ALCB, CEPEC and HUEFS for access to their collections, and FAPESB for financial support provided to the Flora da Bahia project (process APR0162/2007). We thank CNPq for financial support provided to the projects of the Flora da Bahia (processes 562278/2010-9 and 483909/2012), including support for herbarium visits and field expeditions. ISA thanks the Coordenação de Aperfeiçoamento de Pessoal de Nível Superior (CAPES) for the Masters grant and AMG thanks CNPq for her Research Productivity grant (PQ Senior). We also thank Raymond Harley and Simon Mayo for the English translation.

\section{REFERENCES}

Abreu, I.S. \& Giulietti, A.M. 2016 (in press). Flora da Bahia: Aristolochiaceae. Sitientibus série Ciências Biológicas 16: 10.13102/scb1059.

Barros, F.; Araújo, A.A.M. \& Freitas, J. 2015. Aristolochiaceae. In: Lista de Espécies da Flora do Brasil. Jardim Botânico do Rio de Janeiro. Available from http://floradobrasil.jbrj.gov.br/jabot/ floradobrasil/FB54; acessed in 24 Apr. 2015.

Câmara, I.G. 2003. Breve história da conservação da Mata Atlântica. In: C. Galindo-Leal \& I.G. Câmara (eds), The Atlantic Forest of 
TABLE 1: Comparison of Aristolochia brunneomaculata with two morphologically similar species.

\begin{tabular}{|c|c|c|c|}
\hline Characters & A. brunneomaculata & A. tamnifolia $^{1}$ & A. assisii $^{2}$ \\
\hline Habit & climber & climber & herb \\
\hline Petiole length & $0.7-2.6 \mathrm{~cm}$ & $1.2-6.8 \mathrm{~cm}$ & $5.6-16.5 \mathrm{~cm}$ \\
\hline Leaf blade size & $5.3-10 \times 6-11 \mathrm{~cm}$ & $3.5-12.4 \times 3.4-12.7 \mathrm{~cm}$ & $13.8-16.5 \times 11-17.5 \mathrm{~cm}$ \\
\hline Leaf blade texture & chartaceous & chartaceous & membranaceous \\
\hline Leaf blade sinus & $1-2.3 \mathrm{~cm}$ deep & $0.7-2.2 \mathrm{~cm}$ deep & $2.8-4.4 \mathrm{~cm}$ deep \\
\hline Leaf blade apex & acute to mucronate & acute & acuminate \\
\hline Rhipidia: rachis size & $0.8-1.5 \mathrm{~cm}$ long & c. $0.5 \mathrm{~cm}$ long & 0.4-3 cm long, \\
\hline Rhipidia: number of flowers & 1 or 2 & 1 or 2 & $6-23$ \\
\hline Rhipidia: position & ramiflorous or cauliflorous & ramiflorous & ramiflorous \\
\hline $\begin{array}{l}\text { Perianth outer surface: colour at } \\
\text { anthesis }\end{array}$ & yellowish green & vinaceous & beige with small vinaceous spots \\
\hline Lower tube size (utricle) & c. $2.3 \times 1.7 \mathrm{~cm}$ & c. $1.7 \times 1.3 \mathrm{~cm}$ & c. $1.1 \times 0.7 \mathrm{~cm}$ \\
\hline Upper tube length & c. $2.4 \mathrm{~cm}$ & c. $1.4 \mathrm{~cm}$ & c. $1.6 \mathrm{~cm}$ \\
\hline Upper lip shape & elliptic & oval & broadly elliptic \\
\hline Upper lip size & c. $2.2 \times 1.3 \mathrm{~cm}$ & c. $2 \times 0.8 \mathrm{~cm}$ & $1.8-2.0 \times 1.1-1.3 \mathrm{~cm}$ \\
\hline Upper lip margin & not revolute & revolute & revolute \\
\hline Upper lip inner surface & $\begin{array}{l}\text { fimbriae absent or with two } \\
\text { fimbriae near apex }\end{array}$ & covered with fimbriae & fimbriae absent \\
\hline Lower lip size & c. $1.5 \times 1.5 \mathrm{~cm}$ & c. $0.5 \times 1,5 \mathrm{~cm}$ & inconspicuous \\
\hline Capsule form & longitudinally ellipsoid & longitudinally oblong & longitudinally fusiform \\
\hline Capsule size & $2.9-3.3 \times 1.3-1.5 \mathrm{~cm}$ & $3.3-4.1 \times 1.2-1.5 \mathrm{~cm}$ & c. $3.2 \times 1.15 \mathrm{~cm}$ \\
\hline Capsule: rostrum length & c. $0.4 \mathrm{~cm}$ long & c. $0.3 \mathrm{~cm}$ long & c. $1.2 \mathrm{~cm}$ long \\
\hline
\end{tabular}

Based on ${ }^{1}$ Duchartre (1864) and Lewis 817 (CEPEC); ${ }^{2}$ Freitas et al. (2014), Santos 80 (holotype MBML) and Fontana 5884 (paratype MBML).

South America: biodiversity status, trends, and outlook. Island Press, Washington, p. 31-42.

CPRM 2009. Serviço Geológico do Brasil. Atlântico Sul, trecho leste, sub-bacia 50. In: Atlas Pluviométrico do Brasil e Estudos de Chuvas Intensas em Sistema de Informações Geográficas. Available from http://www.cprm.gov.br/publique/Hidrologia/ Mapas-e-Publicacoes/Atlas-Pluviometrico-do-Brasil-1351.html; accessed in Apr. 2015.

Duchartre, P. 1864. Aristolochiaceae. In: A. de Candolle (ed.), Prodromus Systematis Naturalis Regni Vegetabilis. Vol. 15, part. 1. Masson, Paris, p. 421-498.

Freitas, J.; Lírio, E.J. \& González, F. 2013. A new cauliflorous species of Aristolochia (Aristolochiaceae) from Espírito Santo, Brazil. Phytotaxa 124(1): 51-59.

Freitas, J.; Lírio E.J. \& González, F. 2014. Aristolochia assisii, a new neotenic species of Aristolochiaceae from Espírito Santo and Bahia, Brazil. Phytotaxa 163(5): 262-268.

González, F. 1998. Two new species of Aristolochia (Aristolochiaceae) from Brazil and Peru. Brittonia 50: 5-10.
González, F. 2000. A new species of Aristolochia (Aristolochiaceae) from Bahia, Brazil. Novon 10: 371-374.

González, F. 2011. A new pseudostipule-bearing species of Aristolochia (Aristolochiaceae) from Bahía and Espírito Santo, Brazil. Brittonia 63: 430-435.

González, F. 2012. Florística y sistemática filogenética innecesariamente disyuntas: el caso de Aristolochia, Euglypha y Holostylis. Revista de la Academia Colombiana de Ciencias Exactas, Físicas y Naturales 36(139): 193-202.

Hoehne, F.C. 1927. Monographia illustrada das Aristolochiaceas brasileiras. Memórias do Instituto Oswaldo Cruz 20(1): 67-175; t. 16-103.

Hoehne, F.C. 1942. Aristolochiaceas. Flora Brasílica. Vol. 15, part 2. Instituto de Botânica, São Paulo, p. 1-141, t. 1-123.

IUCN 2001. IUCN Red List Categories and Criteria. Version 3.1. IUCN Species Survival Commission, Gland \& Cambridge. Available from http://www.iucnredlist.org/technical-documents/ categories-and-criteria/2001-categories-criteria; accessed in Apr. 2015. 
Nair, N.C.; Dun, D. \& Narayanan, K.R. 1961. Studies on the Aristolochiaceae. I. Nodal and floral anatomy. Proceedings of the National Institute of Sciences of India 28: 211-227.

Neinhuis, C.; Wanke, S.; Hilu, K.W.; Müller, K. \& Borsch, T. 2005. Phylogeny of Aristolochiaceae based on parsimony, likelihood, and Bayesian analyses of trnL-trnF sequences. Plant Systematics and Evolution 250: 7-26.

Ohi-Toma, T.; Sugawara, T.; Murata, H.; Wanke, S.; Neinhuis, C. \& Murata, J. 2006. Molecular phylogeny of Aristolochia sensu lato (Aristolochiaceae) based on sequences of $r b c L$, matK, and phyA genes, with special reference to differentiation of chromosome numbers. Systematic Botany 31:481-492.

Thomas, W.W.; Carvalho, A.M.V.; Amorim, A.M.A.; Garrison, J. \& Arbeláez, A.L. 1998. Plant endemism in two forests in Southern Bahia, Brazil. Biodiversity and Conservation 7: 311-322.

Wanke, S.; González, F. \& Neinhuis, C. 2006. Systematics of pipevines: combining morphological and fast-evolving molecular characters to investigate the relationships within subfamily Aristolochioideae (Aristolochiaceae). International Journal of Plant Sciences 167: 1215-1227. 